\title{
Adding Value to Livestock with Niche Meat Marketing Programs ${ }^{1}$
}

Chad Carr, Larry Eubanks, and Ryan Dijkhuis ${ }^{2}$

The profitability of meat-animal production has declined due to increasing feed, fuel, and fertilizer costs. Therefore, several producers who want to gain a greater portion of the available profit margin are trying to become meat marketers, rather than just livestock marketers. Many of these producers are trying to develop a "niche" or specialty market for their products by socially or emotionally appealing to their target consumers, through some type of "buzz-word" production method (Honeyman et al., 2006). Some of these production methods include, but are not limited to, "organic," "natural,"

"source-verified," "grass-fed," and "outdoor-raised," along with several others. Other producers are trying to market a specialty product that has superior or unique product qualities compared with commodity products (Honeyman et al., 2006). The following report will discuss some opportunities to add value to meat animals through existing specialty meat marketing programs. Additionally, this report will address potential challenges to developing a niche meat marketing program.

\section{Existing Niche Meat Marketing Programs}

Producers who want to add value to their animals via niche markets can decide between one of two options:

- Market their animals through an established niche market

\section{OR}

- Producers can start their own program

Numerous nationally distributed commercial niche markets are available to producers if they are willing to change their genetics and/or production methods to meet the specifications of the program.

Producers who market animals through a pre-existing program will generally receive a premium compared to conventionally raised animals, however, producers who start their own program have the potential to reap greater economic reward. However, these potential rewards come with substantial risk.

1. This document is AN197, one of a series of the Department of Animal Sciences, Florida Cooperative Extension Service, Institute of Food and Agricultural Sciences, University of Florida. Publication date: April, 2008. Visit the EDIS Web Site at http://edis.ifas.ufl.edu.

2. Chad Carr, Assistant Professor; Larry Eubanks, Coordinator of Research Programs; and Ryan Dijkhuis, Biological Scientist; Department of Animal Sciences, Cooperative Extension Service, UF/IFAS, Gainesville, FL 32611.

The Institute of Food and Agricultural Sciences (IFAS) is an Equal Opportunity Institution authorized to provide research, educational information and other services only to individuals and institutions that function with non-discrimination with respect to race, creed, color, religion, age, disability, sex, sexual orientation, marital status, national origin, political opinions or affiliations. U.S. Department of Agriculture, Cooperative Extension Service, University of Florida, IFAS, Florida A. \& M. University Cooperative Extension Program, and Boards of County Commissioners Cooperating. Larry Arrington, Dean 


\section{Starting a Niche Meat Marketing Program}

Developing a successful niche meat marketing program is a complex combination of science, marketing, and economics (NPB, 2004). To address these core aspects of a program, this paper will concentrate on the following:

- Determining the target audience

- Assessing the uniqueness of the product

- Product quality relative to the demographics of the target audience

- Determining a contract packer

- Effective cost analysis

\section{Determining the Target Audience}

Most niche markets start with one of the two following scenarios:

- Potential marketers have an existing supply of livestock but need a target audience

\section{OR}

- Potential marketers have a target audience but need a supply of livestock

If the livestock supply is previously determined, the products could already be aligned for a given target audience. For example, a beef producer whose cattle have extensive fat (marbling) in the muscle should not count on marketing products to dieters. Instead, the given beef producer could try to market products to gourmet restaurants who want to provide consumers more flavorful beef products.

Most established niche meat marketing programs were started by establishing an audience first. The founders then worked backward to identify livestock to meet the target audience.

To determine your target audience, the National Pork Board (2004) suggests asking some of the following questions:
- What are the demographics of my target audience? (age, economic status, lifestyle)

- What is important to them?

- Where do they live?

- How do you plan to market the product? (retail, foodservice or direct to consumers)

For instance, a prospective niche marketer wants to sell retail pork products to individuals in Central Florida. Two prospective audiences for these products would be retirees with a comfortable standard living in a suburban area or well-educated, young working families living in an urban metropolis. Most consumers of all given demographics would probably prefer a locally raised product of comparable quality and value to a national brand (Sloan, 2008). Additionally, consumers from both demographic groups would generally prefer products that have superior or unique product qualities compared with commodity products, particularly if costs were comparable (Andersen et al., 2005; Sloan, 2008).

Distinguishing production methods would add social or emotional appeal to products for many young and middle age consumers and make them "feel good" about feeding those products for their family. These same production methods probably would not affect the purchasing decisions of most retirees. The pace of life and lack of cooking knowledge exhibited by most young families lend themselves to purchasing many easy-to-prepare or ready-to-eat products. Generally, most retirees would not discriminate against longer cooking and preparation times, particularly compared with young families (Andersen et al., 2005; Sloan, 2008). Collectively, the niche marketer should consider two slightly different production and/or marketing strategies based upon which to determine the target audience. More information and further reading can be found at http://www.valuechains.org/pnmwg/projects_reports/ NewProductDevFinalReportRevised.pdf. 


\section{Assessing the Uniqueness of the Product}

Once the target audience and livestock supply have been identified, the production traits of the livestock, the characteristics of the meat products and the demographics of the target audience must be carefully evaluated to produce products which should maximize consumer demand (Parker and Johnson, 2004).

If the production traits or methods of production are not easily distinguished from commodity products, the product may not be unique enough to develop into a niche market. If this is the case, either a different supply of livestock should be identified or the producer of the existing livestock should modify his or her production methods to give the products more identity (Parker and Johnson, 2004).

To assess the uniqueness of your product, the National Pork Board (2004) suggests asking some of the following questions:

-What is my point of differentiation?

- Why would someone buy my product versus a traditional or commodity product?

- Why would someone buy my niche product versus a competing niche product?

\section{Product Quality Relative to the Demographics of the Target Consumers}

It is essential that the supply of livestock, product type, and the given target audience match. This can be assessed by consumer testing. The following is an example of a consumer test ballot (Parker and Johnson, 2004).

Packaging appearance should assess how the product is packaged as well as the product logo. Product appearance as sold should evaluate the product as it is sold to the consumer (fresh, frozen, fully cooked, etc.) and product appearance after preparation should evaluate the product as it is ready to be consumed (Parker and Johnson, 2004). If the given consumers represent the target audience, the collected information is very valuable relative to the given niche market. Information from these tests can be used to determine the most important traits of the product so that it can be adjusted to best emphasize these qualities. Additionally, niche marketers can evaluate competing products to identify areas in which their own products could establish a competitive edge (Parker and Johnson, 2004).

\section{Determining a Contract Packer}

Most livestock producers who aspire to establish a niche market will utilize a contract packer (co-packer) to slaughter and process animals. Potential niche marketers should be very particular when selecting a co-packer to ensure the processor's goals for the niche market correspond with those of the founders (Parker and Johnson, 2004). Generally, medium, small, and very small processing plants are more apt to meet the needs of niche marketers than large commercial processing plants. When possible, niche marketers would be advised to stay with their selected co-packer to promote accountability of quality for both processor and marketer.

\section{Effective Cost Analysis}

After a contract packer has been determined, the proprietor of the potential niche market needs to account for the input costs associated with establishing a start-up company. When calculating a break-even cost, one must be sure to consider the all the following:

- Equipment costs

- Facility maintenance

- Feed costs

- Veterinary costs

- Livestock transportation costs

- Harvest fees and processing charges

- Product transportation costs

- Retail facility maintenance costs

- Advertising costs

- Labor costs 
McCullen (2006) developed a spreadsheet for niche pork marketers which could be modified for most any commodity. The spreadsheet accounts for most of the fixed and variable costs a niche meat marketer might encounter.

\section{Conclusion}

The success of a niche marketing program often depends upon the dedication of the product's founder. Founders who believe in their products will try to find a way for their vision to be established, regardless of the time required. Even so, there are no definitive "silver bullets" to establishing a successful niche meat marketing program. Establishing a niche meat market is a substantial economic risk that takes some margin of good luck to get started. If prospective niche marketers have developed a unique product and have been thorough in developing their product, determining their target consumer, and conducting an effective cost analysis, they have taken some of the major steps to succeed.

\section{Literature Cited}

Andersen, H. J., N. Oksbjerg, and M. Therkeldsen. 2005. Potential Quality Control Tools in the Production of Fresh Pork, Beef and Lamb Demanded by the European Society. Livest. Prod. Sci. Issues 1-2 94: 105-124.

Honeyman, M.S., R. S. Pirog, G. H. Huber, P. J. Lammers, and J. R. Hermann. 2006. The United States Pork Niche Market Phenomenon. J. Anim. Sci. 84: 2269-2275.

McCullen, L. K. 2006. Berkshire Swine Production and Marketing. Available: http://www.nichepork.org/Documents/ Berkshire\%20Production\%20Decision\%20Aids\%208 \%2023\%2006.xls Accessed January 30, 2008.

National Pork Board. 1999. Case Studies of Value-Added Pork Production and Marketing. http://www.nichepork.org/Documents/ valueaddedprodmktngbk.pdf. Accessed January 30, 2008 .

Pork Board. 2004. Six Questions Producers Should Ask. Available:
http://www.nichepork.org/Documents/

sixquestions.doc. Accessed January 30, 2008.

Parker, R. and S. Johnson. 2004. New Product Development for Pork Niche Marketers. A Report Presented to the Pork Niche Marketing Working Group. Available:

http://www.valuechains.org/pnmwg/projects_reports/ NewProductDevFinalReportRevised.pdf. Accessed January 30, 2008.

Parker, R. and Associates and Ashcroft Research. 2005. An Evaluation of the Importance to Consumers of Selected Niche Pork Attributes. Available: http://www.valuechains.org/pnmwg/projects_reports/ Nicheconsumerresearch.pdf. Accessed January 30, 2008.

Sloan,E. 2008. What, When, and Where America Eats. Food Tech., January, 2008, 20-29. Available: http://members.ift.org/NR/rdonlyres/60D3BC0D2113-4C57-BF8D-D5CF36D89E28/0/0108sloan.pdf. Accessed January 30, 2008.

2000. National Organic Program. Washington D.C. http://www.ams.usda.gov/nop/indexIE.htm. Accessed September 7, 2007. 


\begin{tabular}{|c|c|c|c|}
\hline Program & Species & Description & Website \\
\hline $\begin{array}{l}\text { Cattleman's Natural Angus } \\
\text { Beef }^{1}\end{array}$ & Beef & $\begin{array}{l}\text { No antibiotics or growth promotants } \\
\text { for the last } 120 \text { days before } \\
\text { harvesting and always fed } 100 \% \\
\text { vegetarian diet. }\end{array}$ & http://www.cattlemansnaturalbeef.com \\
\hline Abraham's Goat Meat $^{2}$ & Goat & $\begin{array}{l}\text { No production claims- Direct } \\
\text { marketing from producer to } \\
\text { consumer. }\end{array}$ & http://www.abrahamsgoatmeat.com \\
\hline $\begin{array}{l}\text { Maverick Ranch Natural } \\
\text { Meats }{ }^{1}\end{array}$ & $\begin{array}{l}\text { Beef, Pork, } \\
\text { Lamb, \& Bison }\end{array}$ & $\begin{array}{l}\text { Never given antibiotics or growth } \\
\text { promotants, and always fed } 100 \% \\
\text { vegetarian diet. Maverick also offers } \\
\text { a line of USDA Certified Organic } \\
\text { ground beef }\end{array}$ & http://www.maverickranch.com \\
\hline Niman Ranch ${ }^{1}$ & $\begin{array}{l}\text { Beef , Pork, \& } \\
\text { Lamb }\end{array}$ & $\begin{array}{l}\text { Never given antibiotics or growth } \\
\text { promotants, and always fed } 100 \% \\
\text { vegetarian diet. Species protocols: } \\
\text { http://www.nimanranch.com/control/ } \\
\text { protocols }\end{array}$ & http://www.nimanranch.com \\
\hline Slanker's Grass-Fed Meats ${ }^{2}$ & $\begin{array}{l}\text { Beef , Pork, \& } \\
\text { Lamb }\end{array}$ & $\begin{array}{l}\text { Never given antibiotics or growth } \\
\text { promotants, and never fed grain. }\end{array}$ & http://www.texasgrassfedbeef.com \\
\hline Laura's Lean Beef ${ }^{1}$ & Beef & $\begin{array}{l}\text { Never given antibiotics or growth } \\
\text { promotants, and always fed } 100 \% \\
\text { vegetarian diet. }\end{array}$ & http://www.laurasleanbeefcattle.com \\
\hline $\begin{array}{l}\text { Berkshire Meat Products } \\
\text { LLC }^{1}\end{array}$ & Pork & $\begin{array}{l}\text { No production claims- Pork } \\
\text { generated from Berkshire pigs. }\end{array}$ & http://www.americanberkshire.com \\
\hline Coleman Natural Beef ${ }^{1}$ & Beef & $\begin{array}{l}\text { Never given antibiotics or growth } \\
\text { promotants, and always fed } 100 \% \\
\text { vegetarian diet. }\end{array}$ & http://www.colemannatural.com \\
\hline Beeler's Pure Pork ${ }^{1}$ & Pork & $\begin{array}{l}\text { Never given antibiotics or growth } \\
\text { promotants, and always fed } 100 \% \\
\text { vegetarian diet. Additional } \\
\text { production methods: } \\
\text { http://www.beelerspurepork.com/ } \\
\text { Products/Heluka.htm }\end{array}$ & http://www.beelerspurepork.com/ \\
\hline $\begin{array}{l}\text { Coleman Natural } \\
\text { Hampshire }^{1}\end{array}$ & Pork & $\begin{array}{l}\text { Pork generated from pedigreed } \\
\text { Hampshire pigs. Never given } \\
\text { antibiotics or growth promotants, } \\
\text { and always fed } 100 \% \text { vegetarian } \\
\text { diet. Products contain no } \\
\text { preservatives. }\end{array}$ & http://naturalhampshire.com \\
\hline Natural Lamb Cooperative ${ }^{1}$ & Lamb & $\begin{array}{l}\text { Never given antibiotics or growth } \\
\text { promotants, and never fed grain. }\end{array}$ & http://naturallambcoop.com \\
\hline \multicolumn{4}{|c|}{$\begin{array}{l}{ }^{1} \text { Nationally distributed commercial niche programs. } \\
{ }^{2} \text { Homegrown programs. } \\
{ }^{*} \text { National Organic Program: http://www.ams.usda.gov/nop/indexIE.htm }\end{array}$} \\
\hline
\end{tabular}




\begin{tabular}{|c|c|c|c|c|}
\hline \multicolumn{4}{|c|}{ Product Characteristics } & \multirow[t]{3}{*}{ Comments } \\
\hline \multicolumn{4}{|l|}{ Packaging appearance } & \\
\hline 2 & 3 & 4 & 5 & \\
\hline Very appealing & & & Not appealing & \\
\hline \multicolumn{4}{|c|}{ Product appearance as sold } & \\
\hline 2 & 3 & 4 & 5 & \\
\hline Very appealing & & & Not appealing & \\
\hline \multicolumn{4}{|c|}{ Product appearance after preparation } & \\
\hline 2 & 3 & 4 & 5 & \\
\hline Very appealing & & & Not appealing & \\
\hline \multicolumn{4}{|l|}{ Taste } & \\
\hline 2 & 3 & 4 & 5 & \\
\hline Excellent taste & & & Terrible taste & \\
\hline \multicolumn{4}{|l|}{ Texture } & \\
\hline 2 & 3 & 4 & 5 & \\
\hline Excellent texture & & & Terrible texture & \\
\hline \multicolumn{4}{|l|}{ Willingness to purchase } & \\
\hline 2 & 3 & 4 & 5 & \\
\hline \multicolumn{2}{|l|}{ Definitely would purchase } & \multicolumn{2}{|c|}{ Definitely would not purchase } & \\
\hline
\end{tabular}

